\title{
Press - world milestone and Croatia
}

\author{
Bolanča Stanislav, Majnarić Igor, Modrić Damir \\ University of Zagreb Faculty of Graphic Arts, Getaldiceva 2, 10000 Zagreb \\ E-mail: stanislav.bolanca@grf.hr; majnaric@grf.hr; damir.modric@grf.hr
}

\begin{abstract}
The machine printing and rapid cultural development in Europe begins with the discovery of metal lettering at the end of the 15th century. This printing technique has been named the letterpress printing and is one of the greatest inventions of mankind. The development of printing was one of the main indicators of the development of individual countries. We believe that today in the world and in Europe the Croatian development of that age is significantly neglected. This paper presents European development and development in Croatia. This paper will contribute to a more accurate evaluation of Croatian printing and cultural level of that time by displaying Croatian achievements of that era, the printing staff, printed works and printing houses, throughout European and Croatian development of printing.
\end{abstract}

Key words: press, movable types, Gutenberg, glagolitic scripts, incunabula,

\section{Introduction}

\section{Printing up to the year 1440.}

One of the greatest steps in the development of mankind and civilization is the invention of a machine's reproduction of text or image. Before applying such a multiplication of texts and images, humanity has developed slowly by spreading knowledge and transferring it from generation to generation, most often by means of manuscripts and beaming. Realizing the disadvantages of such a system, humanity has always pursued new opportunities to accelerate the multiplication of texts and images. The first reproductions of the original are recorded before $3000 \mathrm{BC}$ in Mesopotamia. These were texts embossed in clay tiles. Also at that time there has been also noted the use of techniques of stamping in China and Egypt ${ }^{1,2,3}$. In China, and then in India, hand-made paper was used for printing, while the printing substrate in Egypt was made from papyrus plants.

Another printing technique dating back to the late prehistoric times is screen printing technique and found in Asia and Europe ${ }^{4}$. Printing technique, using stone blocks or bronze plates as a printing form, is a kind of industrial process and used in Asia from the $4^{\text {th }}$ to the early $6^{\text {th }}$ century. ${ }^{5}$

Replication printing needs were one of the top priorities for research in history. So the wood, as one of the materials that is easily accessible, has been brought into the center of interest. It has become the most important material for making the printing forms (plates). At the beginning, at that time wooden print forms were made as a monolithic printing form - a whole one page of the book. Europeans use xylography (art of engraving on wood, block printing) to produce books and used by European textile makers to print patterns on fabric. 


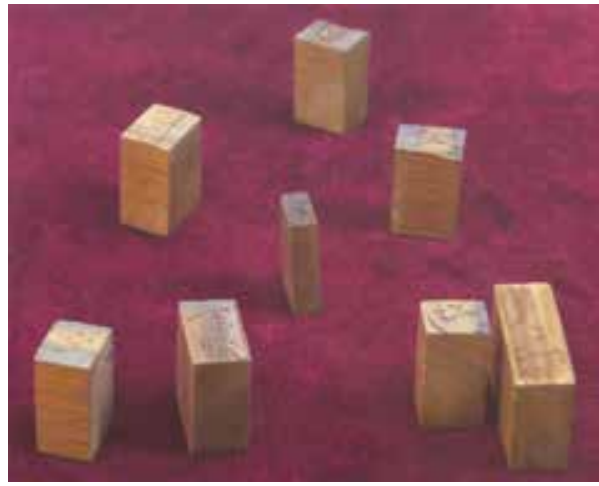

Figure 1. Monolithic wooden printing form for printing whole page ${ }^{6}$

Gradually with the manuscripts, there are also printed books. The oldest known printed book is "Diesruond Sutra" printed in China in the year 868. DC. However, some authors believe that there were books printed even earlier ${ }^{7}$. At this time, monolithic wooden prints were produced for each individual page. In search of a more efficient method of book production, in China, between year 1041. and 1230., invented movable type.

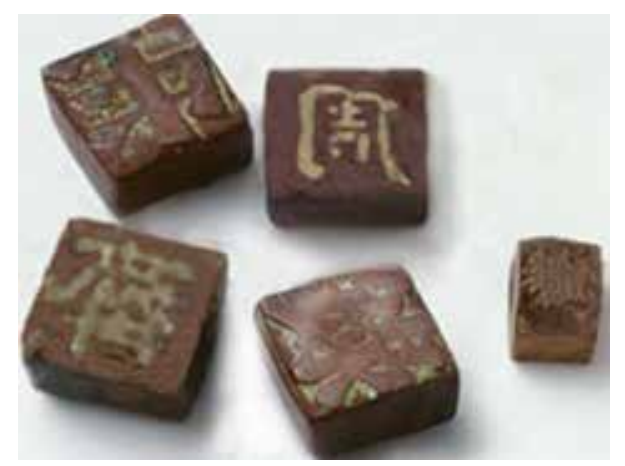

Figure 2. Wooden movable signs for stacking printing form ${ }^{8}$

Wood, as material for the printing form, is gradually replaced by various metals. In the 14th century in Korea were printed books in the Chinese language, and use the movable signs are made of bronze, it was a logical sequence after printing with wooden movable types.

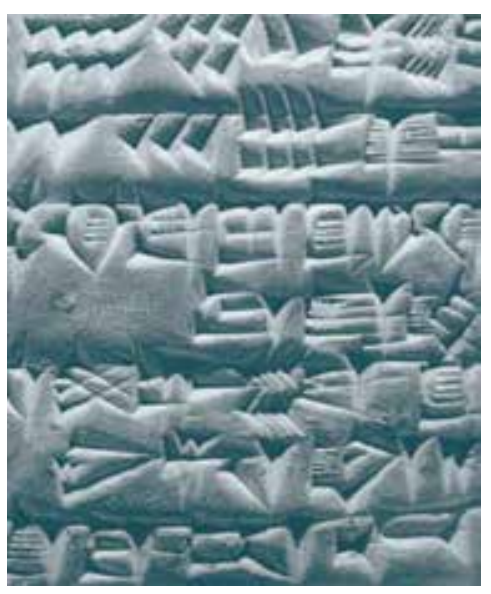

Figure 3. Composite bronze print form for the printing of books. Year approx. $1377 .{ }^{9}$

Chronological order of first book publishing in some area can be seen in the following table 


\begin{tabular}{|l|l|}
\hline 618 - 906 & $\begin{array}{l}\text { Tang Dynasty - The first printed works in contemporary China were printed with a wooden print form on a } \\
\text { paper-based substrate. }\end{array}$ \\
\hline 868 & The book "Diamond Sutra" was printed. \\
\hline 1241 & Movable types were used for printing in Korea \\
\hline 1300 & The first use of movable wooden types in China. \\
\hline 1309 & After China and Egypt, Europe also produces paper. \\
\hline 1392 & Use of movable bronze types in Korea. \\
\hline 1423 & The printing of books in Europe with whole pages on a single printed form. \\
\hline 1452 & Johannes Gutenberg begins in Mainz is using movable metal letters to print the Bible. \\
\hline
\end{tabular}

After the printing technique has spread across the present-day Germany, it is expanding to the rest of Europe and the world.

\section{Gutenberg}

Further, continuous development of industrial multiplication of printed text is based on the invention of movable metal types and platen press in letterpresses technique. Johann Gutenberg began his graphic career in Strasbourg where he participated in the training of the then famous gravure printing machines. He also worked on developing a new printing technique, simpler and less dangerous to human health. Even after leaving France, he continued his research on intaglio and metal typography (letterpress printing) . By the middle of the 15th century, when he moved to the city of Mainz, Johannes Gutenberg invented metal movable letters and replicated books by printing on the machine, by the technique of relief letterpress printing ${ }^{10}$.

The first printing machine, or the letterpress press of the inventor Johann Gutenberg, was made of wood without the use of screws and metal nuts. The dimensions of the presses were 5 to 7 feet in length, 3 feet wide, and 7 feet in height. Next to the machine there was a metal letter foundry. Hard metal letters were impressed into the softer material, resulting in a matrix embedding the individual letters. ${ }^{9}$

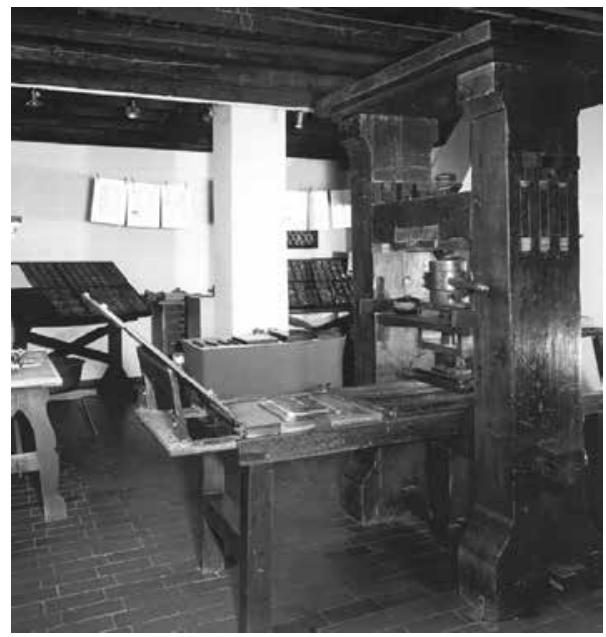

Figure 4. First printing press; Mainz, year $14400^{13.12}$

The machine itself is made on the principle of the locking presses. The press was a large wooden machine that was similar to the presses used to extract oil from olives or juice from grapes. On a flat surface of the base plate, a printed form was formed by stacking individual letters of lead alloy enclosed in a box shape (so called bed of the printing press). Type, small metal letters that have a raised letter on one end, is arranged into pages and placed in a frame to make a form, which itself is placed onto a flat stone, 'bed,' or 'coffin.' Then the ink was hand-applied to the printed form. On the sheet feeding table, the paper tray is mounted manually onto the wooden box-hose and instantly overlap metal frame in precise register to the printing substrate ${ }^{9}$.

The paper pressboard is placed on the metal press form so that the paper lies on the surface of the inked types. Then, wooden spindle was used to guide of the rotation of the spindle towards a downward 
movement of the platen to promote perpendicular movement and so attain a regular impression on the paper. One damp piece of paper was then taken from a heap of paper and placed on the tympan, supported on a flat metal plate called the platen, which sits underneath a second flat plate holding a relief version of the item to be printed (printing plate). The paper was damp as this lets the type 'bite' into the paper better. The printing plate is covered with ink before the paper is pressed tightly against it and then released. The bed is, then, rolled under the platen. Then, using a wooden spindle, the whole "sandwich" of the material was pressed against the platen/ flatbed (a large flat piece of wood), which by its pressure produced the ink transfer from the printing press to the printing substrate. To make the print quality better, a soft cover is placed on the underside of the printing plate. Thus, with the principle of "soft and hard" printing, the process can be repeated any number of times.

The letters of lead alloy were made in thousands of copies in the printing press. The letters were then arranged in print forms. The mirror image of each letter, number or symbol was cut into a small block so it could be recreated easily. Each precast image was easily movable and could be arranged into any order, coated in oil-based ink and lowered onto paper with a screw press. This actually leads to the formation of pages to be printed. "In every printing process, the printing form is the one that takes over the ink and in contact with the printing substrate (paper) and with the action of the appropriate force, leaves the ink in the form of print on the printing medium" ${ }^{14}$. Therefore, all rules must be respected in order for the text and images to be properly positioned and appropriately attached. The preparation of the printing form in the letterpress can be divided into horizontal and vertical ${ }^{15}$. In addition to prepress-makeready on the printing form, it can also be used on printing plate habillage.

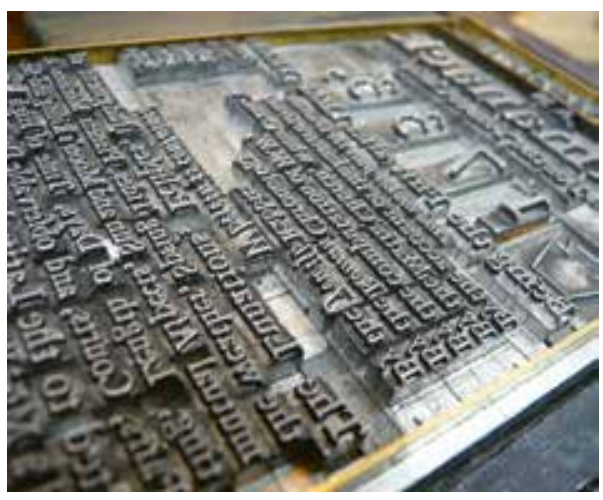

Figure 5. Composite printed form of individual characters of lead alloy ${ }^{16}$

In order for the ink to adhere only on printing elements, they are constructed so that they are higher than the free surfaces. After printing the desired number of identical pages, the print form was disassembled, and the letters returned to the shelf so that they could be used to produce the following printing forms. Because of the printing elements that are higher than the free surfaces, the printing technique mentioned above was named „relief printing”, and name „letterpress printing”. Both names have remained today.

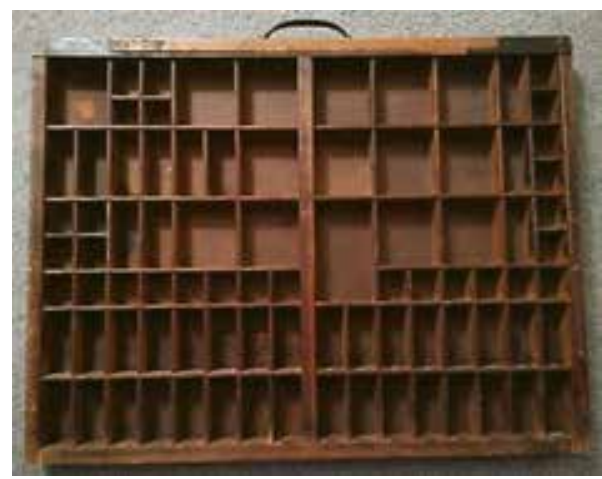

Figure 6. Regal for letters (types) ${ }^{17}$ 
The text is inked using two balls, pads mounted on handles. The balls, called tampons, were made of dog skin leather (it has no pores) and stuffed with sheep's wool and were inked. The old, and today's, graphic symbol is a "dragon" holding these tampons. Today, only a part of that sign is often used, tampons placed one above the other. Development of printing technology comes to master specialization for each stage of printing, and each specialized technological units of the overall process of the press gets its individual coat of arms.

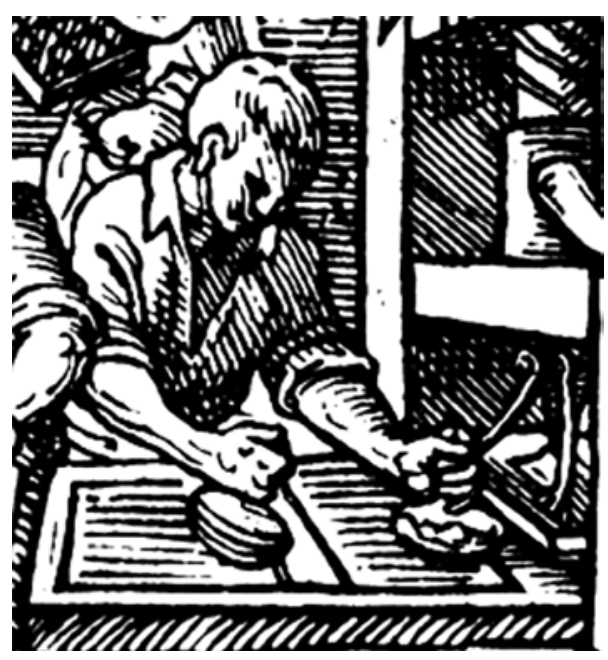

Figure 7. Manual application of ink using the tampon and exposing the prints ${ }^{18}$

The most significant preserved print work in gravure printing techniques using "lead" letters is the print of the Bible. It is believed that Gutenberg's work on the first printed Bible began in $1452^{19}$. At the same time, he printed other more lucrative texts (probably Latin grammar by a scholar named Aelius Donatus). In 1455 he finished his first typographical work. The Gutenberg Bible has 1,272 pages and each page has 42 lines, printed in 100 - 200 copies. A few copies were printed on vellum (calfskin) for higher-quality editions, but most were printed on paper. His capital letters were imitated by Gothic finery. His type case is estimated to have contained around 290 separate letter (type) boxes, most of which were required for special characters, ligatures, punctuation marks, and so forth. Ornaments and illustrations were drawn by hand.

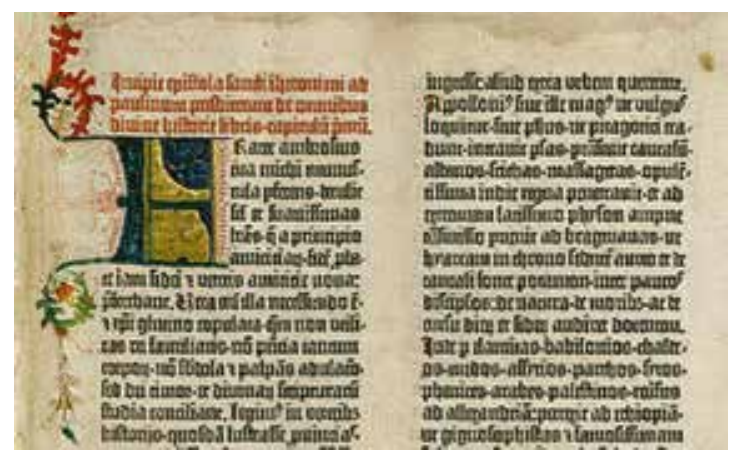

Figure 8. Detail. The text is imprinted with movable letters, the decorations and illustrations are hand-drawn. ${ }^{20}$

This detail is, in fact, an insert from the Gutenberg Bible. The Bible translation is in fact a version of the popular Vulgate from 1455, with the initial 9 pages having 40 rows and the other pages having 42 rows ${ }^{21}$. That is why it is sometimes known as the 42 Line Bible. All pages of the book were printed in two columns. 


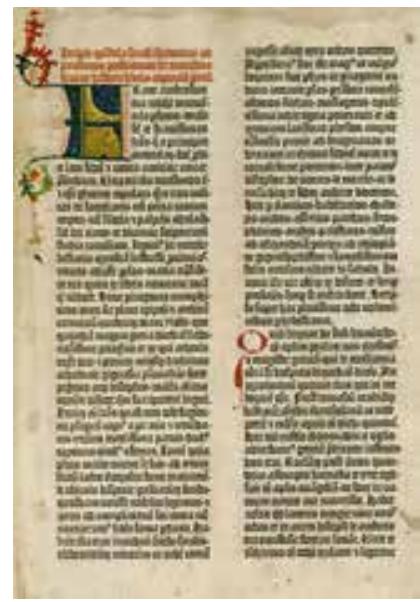

Figure 9. First page of the Gutenberg Bible $e^{22}$

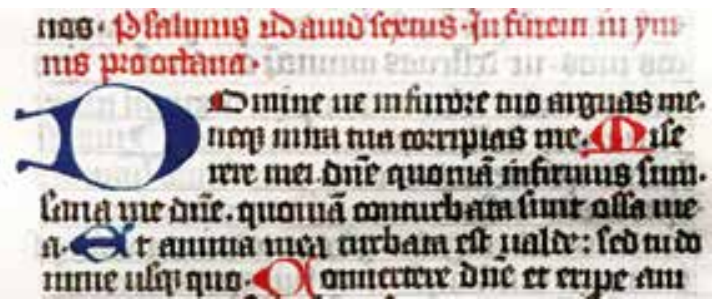

Figure 10. The Gutenberg Bible Specimen ${ }^{23}$

The invention of movable letters is quickly recognized as an epochal invention, one of the greatest in the history of mankind. Accordingly, the graphic artists of that era were particularly respected. In some countries, special laws were written for them, and in some states they were entitled to a nobleman's coat of arms.

Despite the many years he had spent perfecting the printing process; Gutenberg earned nothing from his efforts. Johan Gutenberg was caught up in financial problems due to his ignorance in everyday life and eventually died lonely in poverty.

\section{Printing houses all over the world and Europe}

Until the invention of movable metal letters books, during the Middle Ages in Europe (5th - 15th centuries AD), every book had to be written out by hand. These books were called manuscripts. The majority of manuscripts were copies of various religious texts like the Bible. It took months and sometimes years to complete just one manuscript. Because of the time and skill needed to create just one copy, this meant that books were exceptionally rare and extremely expensive. Books were owned mainly by religious orders, nobility, rich aristocracy, universities and the very rich. With very little or no access to books, most people in the Middle Ages did not learn to read and because of this, they knew very little about the world around them. Although the press existed long before Gutenberg's invention, sudden development of the print, especially books, is based on his invention. As time passed, the printed word became increasingly widespread with Europe and the world. The increase in printed titles in Europe from 1450 to 1800 is shown by the following histogram. 


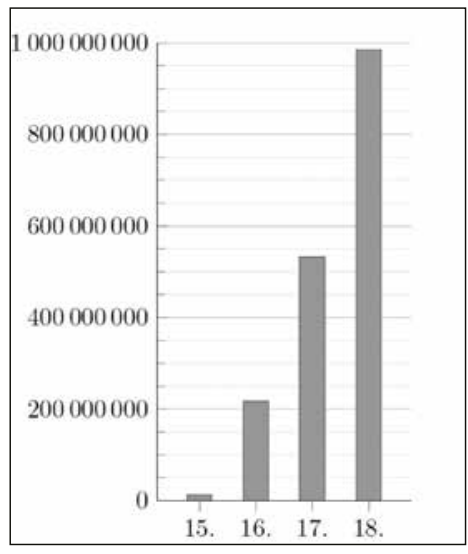

Figure 11. Histogram of European production of prints from 1450 to $1800^{24}$

The histogram shows that the number of prints in the 15th century was relatively small, about 12 million prints. But as early as the 16th century, over 200 million printers were printed. The increase continued in the 17th century, when the number of prints grew up to nearly 450 million copies, while in the 18th century the number of prints reached nearly one billion copies.

It is this kind of dazzling development and growth of production which shows the exceptional the invention of printing, which opened the approach of science and art to the wider world. Facilitated recorded writing, replication of the written record, and access to writing is in fact the foundation of the development of science and civilized society.

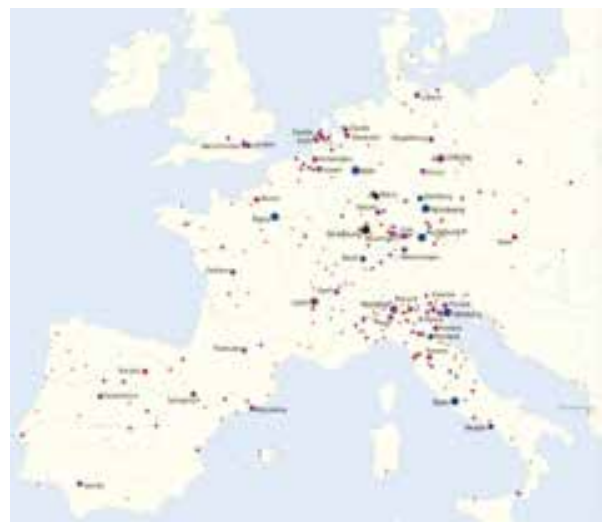

Figure 12. The distribution and location of printing houses until 1540 in Europe ${ }^{25}$

The rapid economic and socio-cultural development of late medieval society in Europe created favorable intellectual and technological conditions for Gutenberg's invention: the entrepreneurial spirit of emerging capitalism increasingly made its impact on medieval modes of production, fostering economic thinking and improving the efficiency of traditional work-processes. The sharp rise of medieval learning and literacy amongst the middle class led to an increased demand for books which the time-consuming hand-copying method fell far short of accommodating ${ }^{26}$.

Figure 12 shows that the first printing houses emerged mostly near the town of Mainz. This is understandable if one takes into account the communication links at that time, especially between distant areas. Thus, most of the printing houses of that time were opened in today's Germany and France, which had already developed the printing with other printing techniques. Somehow, at the same time, some printing houses were opened in Italy and Spain, a very important area of the Mediterranean. The development and expansion of the number of printers over time is shown as follows ${ }^{26}$ : 


\begin{tabular}{|l|l|}
\hline Strassburg & 1458. \\
\hline Vienna & 1462. \\
\hline Basel & 1464. \\
\hline Köln & 1465. \\
\hline Eltville & 1467. \\
\hline Augsburg & 1468 \\
\hline Nürnberg & 1470 \\
\hline Ulm & 1472. \\
\hline Spain and England & 1473. \\
\hline Mexico & 1593. \\
\hline
\end{tabular}

All the European countries wanted to develop as fast as possible, and as their centers of culture, they opened printing houses. Of course, it required the advanced technology, as well as the progressive economic and political milieu. In accordance with its capabilities, Europe has risen into a new civilization period.

Thus the diffusion of the printing press in the territory of many of today's countries ${ }^{27}$ :

\begin{tabular}{|l|c|}
\hline Germany and Austria & 36 printing presses \\
\hline Italy & 16 \\
\hline Switzerland & 21 \\
\hline France & 11 \\
\hline Spain & 7 \\
\hline Belgium & 6 \\
\hline Netherlands & 1 \\
\hline Hungary & 2 \\
\hline Poland & 4 \\
\hline Czech Republic & 4 \\
\hline England & 2 \\
\hline Denmark & 2 \\
\hline Sweden & 5 \\
\hline Portugal & 2 \\
\hline Croatia & 1 \\
\hline Montenegro & 1 \\
\hline Turkey & \\
\hline
\end{tabular}

Of course, the increase in the number of printing presses and the increase in printed works implied the technical development of printing machines. But essential design idea of first Gutenberg printing press remained until the end of the twentieth century.
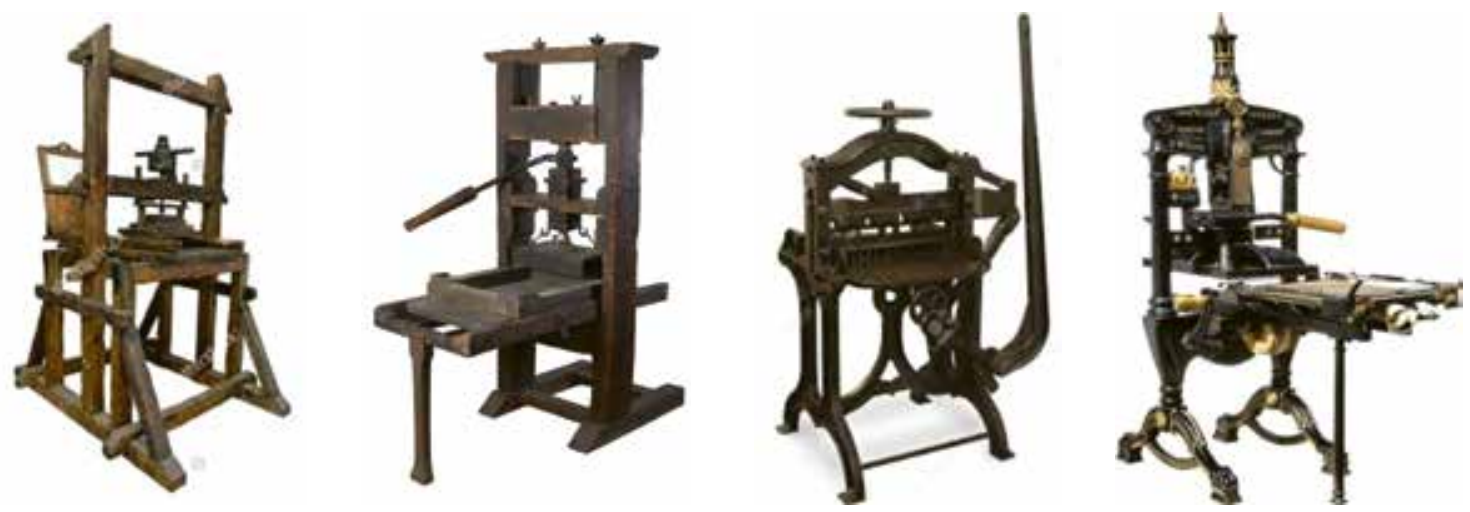

Figure 13. Technical development of printing presses through time ${ }^{32}$

The pictures shown show the technical development of the printing press construction. The first presses were built almost entirely of wood. They are followed by presses with an increased portion of iron parts, for example iron nuts on screws. Further development goes in the direction of leaving the wood, and only switches to iron. The development of locking press machines continues through the 
centuries. Their production almost completely ceases at the end of the 20th century, and a specimen of a locking machine from that time is shown on the last picture.

The pictures shown show the technical development of the printing press construction. The first presses were built almost entirely of wood. They are followed by presses with an increased portion of iron parts, for example iron nuts on screws. Further development goes in the direction of abandoning the wood as a material for making presses, and the transition to exclusively use of iron. The development of letterpress machines continues through the centuries, but their production almost completely ceases at the end of the 20th century, and an example of a locking machine from that time is shown on the last picture.

\section{Incunabula: The Early Printed Books}

"Incunabula" is a generic term coined by English book collectors in the seventeenth century to describe the first printed books of the fifteenth century. The term Incunabula (also incunabulum) refers to a book, pamphlet or other document that was printed, and not handwritten, before the start of the 16th century in Europe. The first recorded usage of the term incunabula came in 1639 when the noted bibliophile Bernhard von Mallinckrodt issued a pamphlet to mark the bicentenary of the advent of printing by movable type titled De ortu et progressu artis typographicae ("Of the rise and progress of the typographic art").

Johann Gutenberg was followed very quickly by other graphic artists and other printer houses. High quality printing staff and, in that time, high quality technical equipment provided a cultural and civilization milestone. The general education grew rapidly, and the wider parts of society began to participate in some, until then, for them impenetrable life activities. All this is made possible by producing quality prints on a large scale and by lowering the prices of individual copies.

The works printed in the 15th century are called "incunabula" - the original (lat. Incunabulum - cradle - the beginning of something) ${ }^{37}$. Unlike previous books, incunabula includes books, leaflets or illustrations that are not handwritten but are mechanically printed before 1501 in Europe. Samples of such books today are extremely valuable ${ }^{38}$.

The printing of the Bible and many other well-known sacral works began with Gutenberg. This also leads to the need and development of translation from foreign languages. According to some sources, other printing material, such as playing cards, has also been reproduced.

Considering that only about 10 per cent of the western European population was literate in 1400 , books were used and enjoyed by privileged minority. The $15^{\text {th }}$ century also marks the beginning of urban patronage, characteristic of the rise of an identifiable bourgeoise. In the early 1450's rapid cultural change in Europe fueled a growing need for the rapid and cheap production of written documents. By printing a large number of capital works and books, they become available to a wider population, and as an example it can be stated that in 1461. was printed the collection of fables entitled Der Edelstein ('The Jewel') written by Ulrich Boner. It was printed at Bamberg diocese by Albrecht Pfister and was one of the first books printed in the German language. Editions of Boccaccio, Aesop, Ptolemy, and Terrence, flowed from these presses and the images that were created in Ulm define the illustrated book in Northern Europe. Here are for illustrations imprint still used wooden printing forms. From its European debut in the 12th century, paper gradually proved to be a viable alternative to the animal-skin vellum and parchment that had been the standard means of carrying written communication. Rag paper became increasingly cheap and plentiful while literacy expanded; the two processes accelerated, in part, by stimulating each other. This cultural revolution, however, had begun much earlier, in the mid-14th century through the figures of Francesco Petrarca (1304-1374) and Giovanni Boccaccio (1313-1375), who can be considered the first two bibliophiles of the modern era. They were the first who really realized the significance of recovering the works of classical authors and started gathering and copying manuscripts with the purpose of establishing a new kind of library, not only based on the Holy Scriptures and on the Church Fathers. Petrarch's library can be considered the first modern library. 
Visual art also benefited from the multiplication of Albrecht Dürer's work, and, with his help, incurred the most beautiful books of the 16th century. Albrecht Dürer was a brilliant painter, draftsman, and writer, though his first and probably greatest artistic impact was in the medium of printmaking. Dürer apprenticed with his father, who was a goldsmith, and with the local painter Michael Wolgemut, whose workshop produced woodcut illustrations for major books and publications. An admirer of his compatriot Martin Schongauer, Dürer revolutionized printmaking, elevating it to the level of an independent art form. He expanded its tonal and dramatic range, and provided the imagery with a new conceptual foundation.

The printed book at the turn of the 15th and 16th centuries also plays a special role in Martin Luther's work when many of the titles on the reform of the church are printed. Printing was essential to the creation of Martin Luther, but Luther was also a determining, shaping force in the German printing industry and after Luther, print and public communication would never be the same again. Luther plays master role in the imagination and execution of what had to have been the world's first mass-media-driven revolution. Luther didn't just reimagine the Christian faith, he figured out how to share his vision through the innovative use and manipulation of a nascent communications technology: the printing press.

Given the social, economic conditions, and in accordance with the technical possibilities, editions at that time were relatively small although some religious works were printed in huge print runs of up to 200,000 copies. . For example, in Italy the new media flourished like nowhere else in Europe. In a few decades, Italy, thanks to its extensive sales network and the presence of numerous and prestigious universities, became a great center of evolution of the press and eventually surpassed Germany itself: 4157 editions were printed in Italy from 1465 to 1550, as opposed to the 3232 issued in Germany, 998 in France and 395 in the UK. Considering an average press run of about 400 copies, ranging from the 200 at the very beginning to the over thousand copies of the end of the century, we may calculate that over 15.000.000 books were produced in the peninsula during that period of time. With the existing technology of the time, the realization of such large projects lasted for several years.

\section{The Invention and History of the Printing Press}

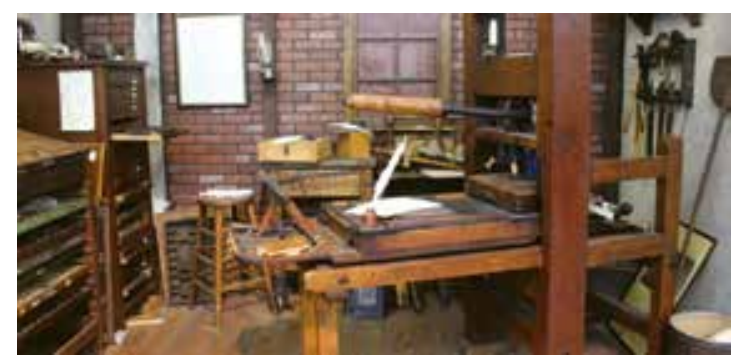

Figure 14. Master printing house for printing Inkunabula ${ }^{39}$ http: //www.psprint.com/resources/printing-press

Gutenberg developed his press by combining features of existing technologies: textile, papermaking and wine presses. Perhaps his most significant innovation, however, was the efficient molding and casting of movable metal type. Gutenberg began experimenting with metal typography (letterpress printing) after he had moved from his native town of Mainz to Strasburg around 1430. Knowing that wood-block type involved a great deal of time and expense to reproduce, because it had to be hand carved, Gutenberg concluded that metal type could be reproduced much more quickly once a single mold had been fashioned. Each letter was carved into the end of a steel punch which was then hammered into a copper blank. The copper impression was inserted into a mold and a molten alloy made of lead, antimony and bismuth was poured in. The alloy cooled quickly and the resulting reverse image of the letter attached to a lead base could be handled in minutes. In order to do this, he had to form the printing letters as opposed to the ones written. Then all the text was printed in the reverse order because the bookshop is a direct printing. 
Small images of each letter (earlier words or phrases) were engraved in small relief blocks. The individual letters were easier to match, and so the words were created, the words slid into the lines, and lines along the pages. Such a stack could fill each format and print every text ${ }^{40}$.

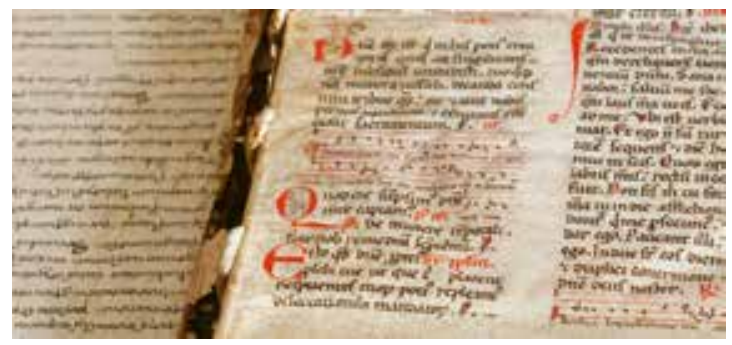

Figure 15. Incunabula, large volume copy commonly artistically bound ${ }^{41}$

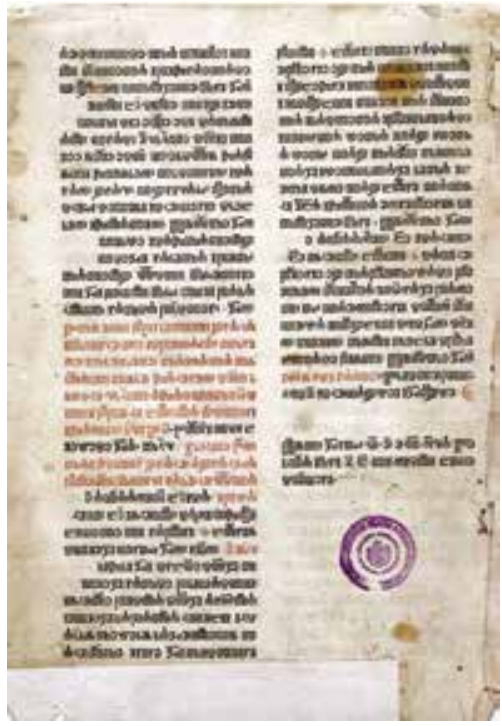

Figure 16. The interior look of a very complex incunabula content ${ }^{42}$

Today, most of the remaining incunabula are stored in appropriate safe places where they are kept under the satisfactory conditions that ensure their longevity. The enemies of all old documents are heat, humidity, and sunlight. To maintain their fine condition, they should be kept in a stable storage environment free of excess fluctuation in temperature and humidity. There should limited contact with air and strong light. For most of these works, it's well known where they are kept, but some have lost their tracks.

\section{Printing houses in Croatia}

An important parameter for determining the degree of civilization and economic power at the end of the 15th and early 16th centuries is the possibility of graphic reproduction of written originals, possession of printers and cadres capable of satisfying them. Historical data and works are being kept today, which confirm the degree of printing and culture development of individual states and cities. Unfortunately, in many world centers, Croatia is not even mentioned or mentioned very modestly, sometimes with inaccurate data. In order to at least improve this situation, we will describe some segments of Croatian history at the beginning of the printing industry's creation, that is, at a time when the culture and the informing of the people rose to a higher level.

Senj has apparently been inhabited since prehistoric times. A confirmation of the development of the settlement is the foundation of the diocese in Senj (Pope Alexander III in letter 1169 orders the Senj bishop Mirej to obey the Archbishop of Split as well as his predecessors). In the second half of the 15th and early 16th centuries, Senj is on the safest transit route from the coast to the hinterland. In 1489, there was the consulate of the city of Ankonia and Dubrovnik Consulate. Senj is the most important 
city in the coastal area outside the territory of the Dubrovnik Republic and Venice Dalmatia. In its turbulnt history Senj falls under many rulers. Thus, for example, Bela III. gave the city of Senj to the Templars, which was confirmed by Pope Lucius III in a letter dated November 22, 1183 or 1184 . In the year 1271 it became the property of the Frankopan counts of Krk who ruled Senj almost two centuries. The power of Frankopan counts of Krk melts away before the danger of Turkish invasion. They cannot provide security and protection to the subjects before the onset of danger. Concerned Senj citizens seek protection from the Venetians, the Pope and the Habsburgs, causing the worries of Croat-Hungarian king Matijaš Korvin. So, in November 1469 Blaž Podmanicki (Blaž Majer or Hungarian) took over, in the name of King Matijaš, authority in Senj. It is well-known that in the period of incunabula, Venice was, due to economic gains, preserved and watched the production of printed books. Senj alone can claim that he had a printing house in that period. All printing activities in Senj were in the Old Slavic and Croatian languages. ${ }^{43}$

Croatian glagolitists and transcribers enthusiastically accepted Gutenberg's invention of multiplication of printing books. Only 28 years after Gutenberg's first edition of the Bible, in Istria (most likely in Kosinj) Missal is prepared for print, which was printed in Glagolitic 1483. However, many sources claim that one year before Senj, in 1483 there was a printer in Kosinj, the largest settlement in northern Velebit. There is a lot of relevant evidence for the existence of this printing house, but this is the first printing house, for which it is undoubtedly known that it is acting on Croatian soil. "It is believed that Frankopan principals in Kosinj founded the first Croatian printing house. It is assumed that in 1483 it was printed for church purposes, the first printed book in the Croatian language (more precisely, to the Church Slavonic language of Croatian redaction), Missale Romanum Glagolitice. Venice is referred to as the second location for the printing of Misal from 1483." ${ }^{4}$

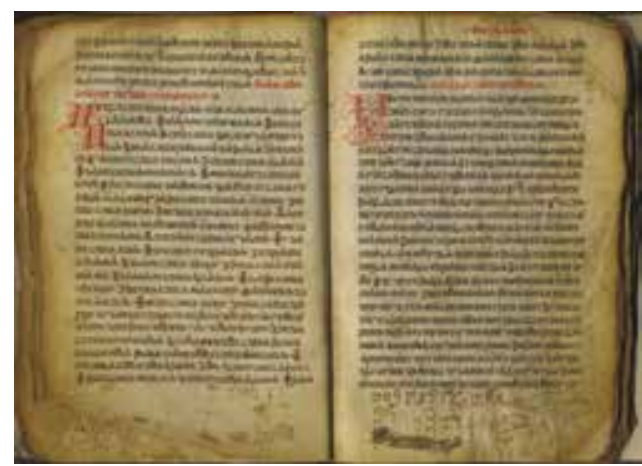

Figure 17. A copy of the Croatian first edition (prvotisak) from 1483, which is kept in the National and University Library in Zagreb ${ }^{47}$

According to some sources, the printing house of Kosinj moved in Senj, to be leaned against the Turkish invasion. By not knowing the true state of glagolitism in the Middle Ages, there was a belief that Glagolitics were poor and at a low cultural level. However, this arbitrary rating changes in the second half of the 20th century. The false image of the poverty and cultural inferiority of medieval glagolitans was created by the fact that from the second half of the 16th century to the 19th century, the Glagolitic clergy were in economic difficulties and because of the inability to attend higher education institutions. With the Turkish conquest, the glagolitic area was reduced to the narrow and poor coastal area of Dalmatia, Kvarner and Istria and remained separate from its hinterland.

The printing house in Senj used a Glagolitic script, because use of these types was at that time already deeply ingrained in Senj. This is also confirmed by the Senj stone slab from the eleventh century, which was written with already developed glagolitic script. In 1248, the Roman Pope gave a written permission to Senj's Bishop Filip to perform liturgy in the Croatian language using the Glagolitic Church books. 


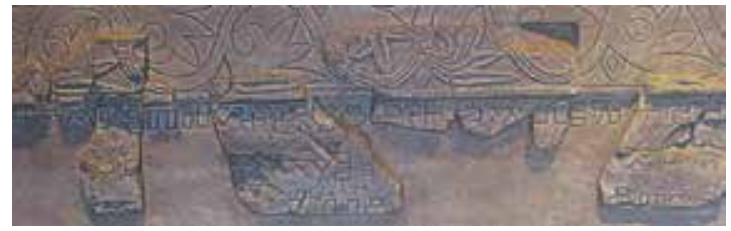

Figure 18 The Glagolyan stone tablet of Senj from the 11th Century ${ }^{48}$

The printing of books in Senj takes place in two time periods: 1494-1496. and 1507-1508. year. Numerous people have been involved in the printing of Glagolitic books in Senj. Their names are men-

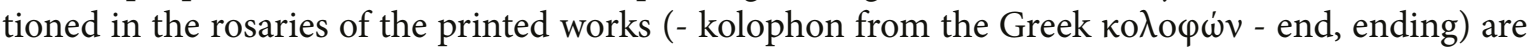
the data usually found at the end of the book.) They contain information about the printer, place and year of printing. Some of those people were mentioned as printers, some as translators and some as collaborators without special specifications. One of the most prominent workers involved in the early publishing of Glagolitic books was Blaž Baromić, a priest and canon of Senj. Blaž Baromić in the beginning of his career transcribed religious books in Vrbnik. From there he went to Venice, where he taught print art and worked in Toresani's print shop, where in 1493 he published a breviary in press. He participates in printing a breviary for the needs of the Senj Diocese. The breviary was printed in Glagolitic in 1493.

Blaž Baromić then moved to Senj where he printed the Senj Misal. It is the first book printed on the Croatian soil, with the Croatian script - glagolitic, and it was printed in 1494. The printing was done by a wooden press in the Senj printing press of the approximate layout as shown in Figure 19.

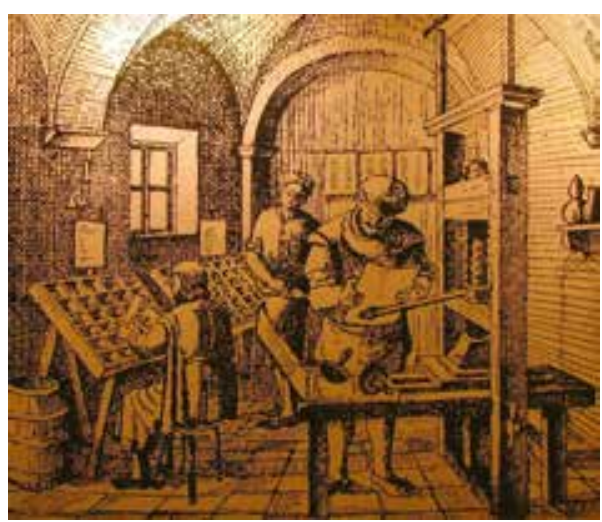

Figure 19. Approximate look of Senj printing hause from the end of the 15th century ${ }^{48}$

From a technical point of view, the prints were very high quality, but for its beauty, many authors consider Senj Misal as one of the most beautiful books and the greatest graphic work of art of its time.

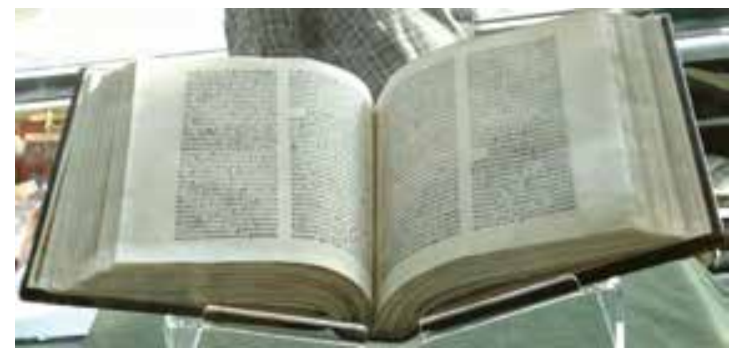

Figure. 20. Prints of Senj printing house ${ }^{48}$

In order to understand it better and to get closer to the events from the 15th to 16th centuries, it was decided to build in Senj authentic replica of Baromić press. It was a significant project that was approached in a way scientists studying the past with all relevant factors. The initiators of the project were Matica hrvatska Senj, Faculty of Graphic Arts from Zagreb University, Senj Museum and organizers of Croatian Graphics Symposium. The main bearer of the project was prof. Dr.Velimir Salamon. The result of the efforts to reconstruct the old press is the press in the Senj Museum. ${ }^{49}$ 


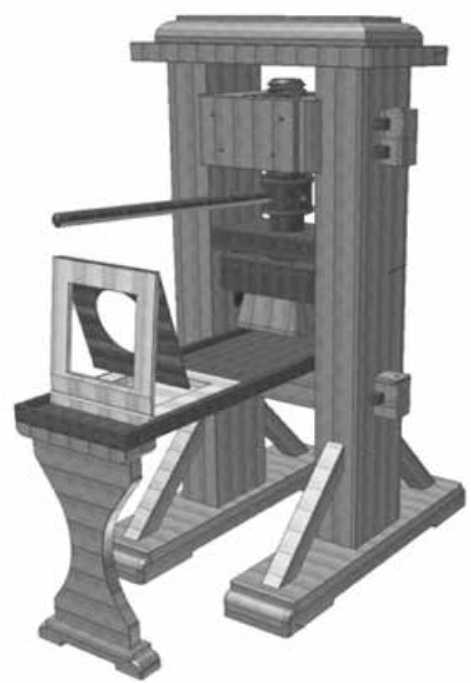

Figure 21. The reconstructed Blaž Baromić's printing press in Senj ${ }^{49}$

Before Senj and Kosinj on the territory of Croatia, the beginnings of graphic activity appears on the already existing Glagolitic cultural heritage. Roc is mentioned in the records for the first time in 1064. The church in Roč already compiles the "Glagolitic alphabet" around 1200. In particular, the first Croatian book Misal under the law of the Roman court dating from 1483 was prepared for printing in Roč. It is known that the prepress is carried by Juri Žakan, using a Glagolitic hot type, but unfortunately, this book was not printed on Croatian soil.

Today, Roč has about 150 inhabitants. The Katedra Čakavskog sabora (Chair of Chakavian Council) from Roč in 2000 achieved a significant project and enriched Roč with the replica of Gutenberg's Glagolitic printing presses, and an extraordinary work for glagolitic and Croatian culture - "Aleja glagoljaša". It is alley along which are made stone signs of Glagolitic alphabet and other cultural features, and extends from Roč to Hum.

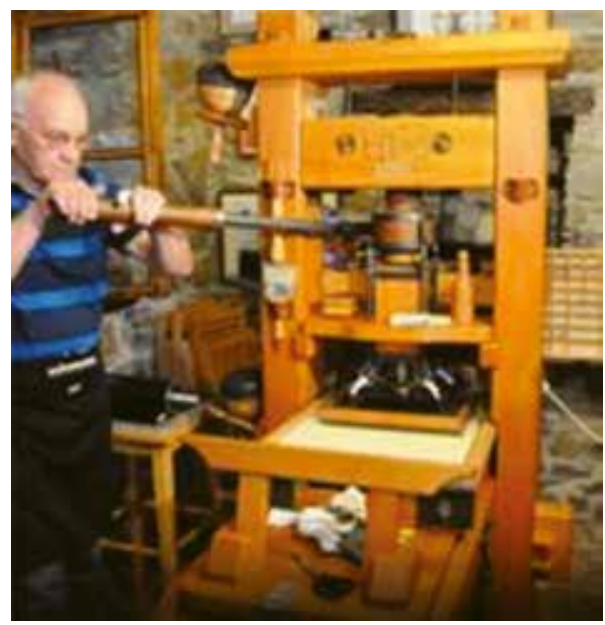

Figure 22. Replica of the Gutenberg press in Roč today. ${ }^{51}$

The place known for its glagolitism is also Vrbnik on the island of Krk. Blaž Baromić was born in Vrbnik, and he left the trace by transcribing the Breviary of pop Mavro in 1460. This breviary is written in glagolitic script in the Croatian editorial office. In Vrbnik there was a replica of printing presses from the 15th to 16th centuries, in memory of Blaž Baromić and Dragutin Parčić. Through the efforts of Dragutin Antun Parčić, a Croatian linguist from Vrbnik on the island of Krk, a Glagolitic missal was returned to the original Croatian Church Slavonic language. 

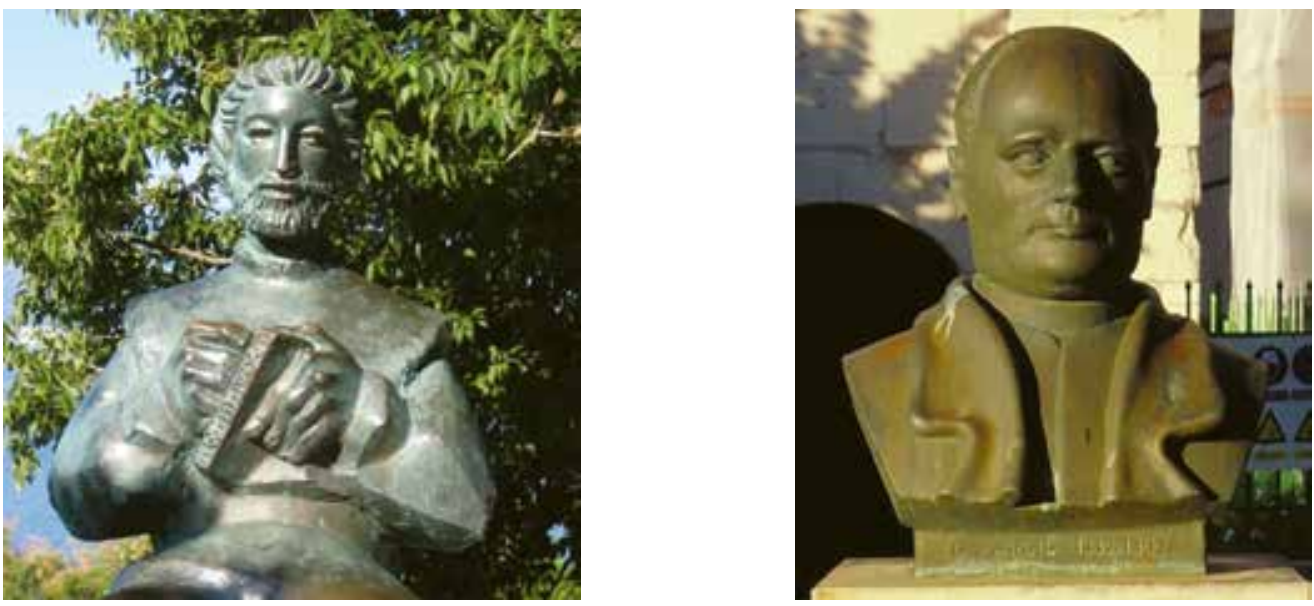

Figure 23. The first and the last Glagolitic Printers: Blaž Baromić and Dragutin Parčic ${ }^{52}$

The printing press which is today in Vrbnik, as well as the one in Roč, is in fact the reconstruction of Gutenberg, and the author of these reconstructions is Frane Paro. These presses are a reminder of their time, the civilization stage of this region in the past, and are also available to tourists who want to get acquainted with Vrbnik's history.

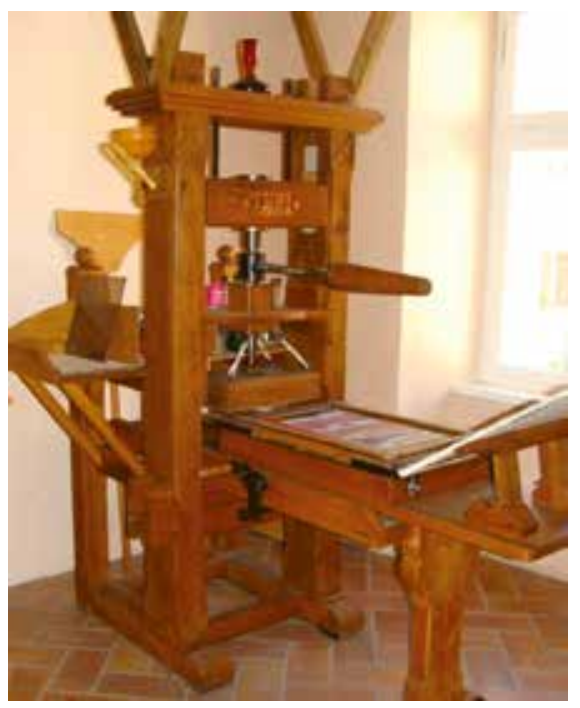

Figure 24. Vrbnik printing presses - replicas ${ }^{54}$

Franciscan bishop Šimun Kožičić Benja (around 1460-1536.) founded a printing house, on the Croatian coast, in Rijeka and in it in 1530 and 1531 with the help of master Goran Maravček (stampadur) printed six Glagolitic books. 


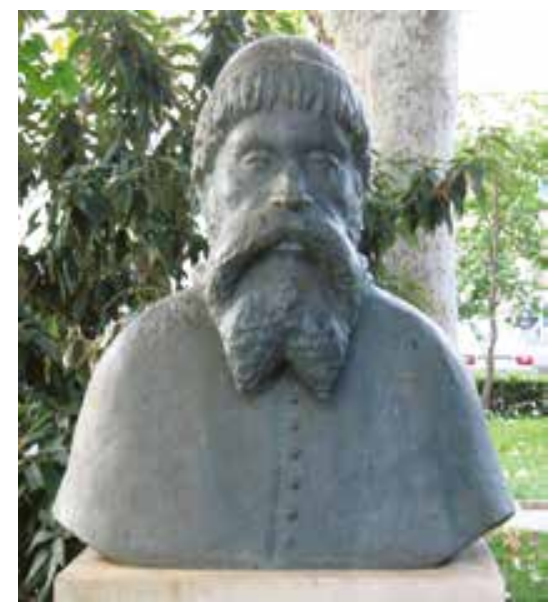

Figure 25. Bishop Šimun Kožičić Benja Glagolitic and publisher ${ }^{56}$

The period of Gutenberg's discovery of printing books with movable types resulted in the flourishing of printing and publishing. Thus appears the first printing house in northern Croatia, in Nedelišće (Međimurje). The first preserved work printed with kajkavian dialect, Decretum of Ivan Pergošić (? - 1592) was published in 1574 in Nedelišce. It is a part of the Latin translation of the feudal law, confirmed by King Ladislav, that is, on the proceedings of the Croatian-Hungarian private law, which contains the aggregated legal norms in Hungary, Croatia and Erdog (Transylvania) that were in force until the appearance of the Austrian Civil Code in 1853 . The author of the Latin source is Istvan Werböczy (1458-1541) and was first published in Vienna in 1517 and during the next three centuries it was reprinted twenty times in Latin and the same number of times in Hungarian. The structure is three-part so it is called the Tripartition (the first book has 134 Titles, the other 86, and the third 36). Since it is a law, Decretum is rich in legal terms, mostly newborns, which testify about the construction of kajkavian terminology and administrative functional style since the first printed book. A replica of the printing press is now made, and as an exhibit can be seen in its useful function., ${ }^{57}$

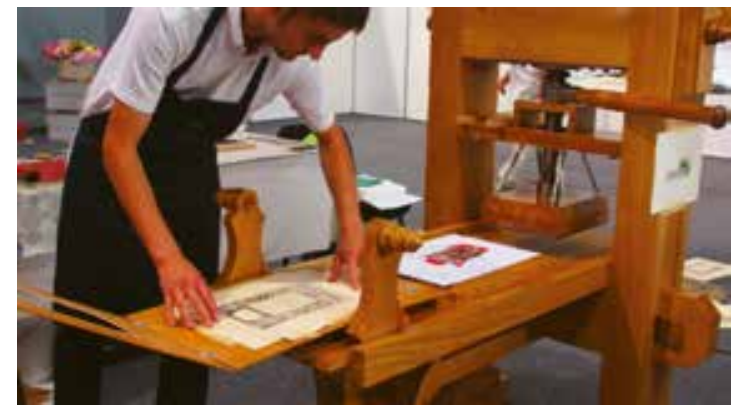

Figure 26. Replica of press from Nedelišće (16th century) ${ }^{58}$

In the 16th century there were more printers in Croatia, but the above mentioned shows that this part of the world lived and worked at a high cultural level.

\section{Conclusion}

From time immemorial, one major difference between humans and other living beings was the power of recording events and experiences. In this way, knowledge was easier to spread and even easier to pass from generation to generation. The first revolution in human communications was the invention of writing. This event dates back many thousands of years to the ancient kingdoms of the Middle East. The written word allowed rulers to publish declarations, merchants to keep track of their trade, and storytellers to record their myths and tales. The next step was to duplicate the record. The craft of printing did not begin until the eighth century A.D. in Asia. In ancient Japan, Korea, and China, the first printers carved characters into wooden blocks, spread them with ink, and then pressed the blocks down on paper or fabric. In the 1040s, Pi Sheng also experimented with movable type by carving the 
characters into blocks that could be arranged for printing. In the Far East, movable type and printing presses were known but did not replace printing from individually carved wooden blocks, from movable clay type, processes much more efficient than hand copying. The use of movable type in printing was invented in $1041 \mathrm{AD}$ by Bi Sheng in China. Since there are thousands of Chinese characters, the benefit of the technique is not as obvious as in European languages. Reproduction also appears in other parts of Asia, Africa and Europe. While Chinese and Korean artisans were creating methods for printing books with machines, copyists in Europe continued to reproduce manuscripts by hand. Many of these scribes were monks who lived in isolated communities and spent their days laboring at small desks, writing out religious texts, hymns, and prayers. Using quill pens, they had to copy a text word for word on a piece of stiff parchment. Bookbinders then secured the individual pages of each manuscript between a set of wooden or leather covers. Unfortunately, the lack of communication and some political impacts does not lead to joint development in geographically remote areas.

Civilization has always been further developed and research work required duplication of the original. Gutenberg began experimenting with metal typography (letterpress printing) after he had moved from his native town of Mainz to Strasburg around 1430. Knowing that wood-block type involved a great deal of time and expense to reproduce, because it had to be hand carved, Gutenberg concluded that metal type could be reproduced much more quickly once a single mold had been fashioned. Each letter was carved into the end of a steel punch which was then hammered into a copper blank. The copper impression was inserted into a mold and a molten alloy made of lead, antimony and bismuth was poured in. The alloy cooled quickly and the resulting reverse image of the letter attached to a lead base could be handled in minutes.

The development of multiplication of the original by letterpress graphical printing begins in Mainz. Since Germany was divided into many small states, and each of them wanted to be leader, they started to establish printing houses. At the same time, all the major cities of the advanced European countries open their own printing houses in order to stimulate their cultural and economic development. At that time, the first Croatian printed book Misal printed by the law of the Roman court, printed in Glagolitic script, was printed. The printing was completed on February 22, 1483, 9 years before the discovery of America or 10 years after the Battle of Krbava. The Turk conquests, of course, disturb the rapid and peaceful development in Croatia.

At that time, although much of Central Europe is rapidly developing, Croatia, despite being pushed into wars, very successfully follows printing developments. In our opinion, this is not well valued in the world professional community. Thus, for example, the Gutenberg Museum in Mainz on a map that speaks of the spread of Gutenberg's discovery of printing techniques in Europe does not give information about the Senj printing house ${ }^{60}$. Nevertheless, Kosinj was mentioned as a printing house in 1483. This neglect of the existence of the Croatian culture of that time can be seen from very rare reference of our printing presses and our publications in relevant international institutions.

As proof of the Croatian place in the culture of Europe of that era, "...it should be noted that in 1496 the first non-Biblical book on Croatian soil and in the Croatian language ("Spovid općena") was printed. This manuscript puts Croatians and Croatia in a number of small, rare nations and countries that, before 1500, with their own forces (printers, processors, bookbinders are local people) print their books in their own language and in their letter". ${ }^{60}$

The expertise of Croatian printers was very high. This can already be seen from the paper format and book budget. Thus, in the relatively simple book "Sprovid općena", the first Croatian printing sign was constructed and placed on it. 


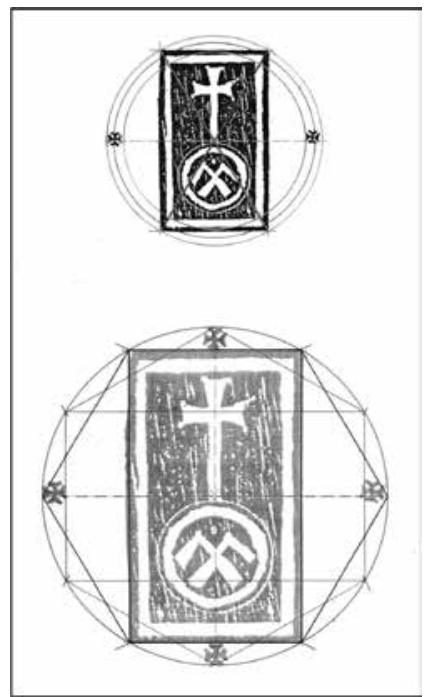

Figure 27. Geometric proportions $1: \mathrm{v}^{3}$ (sikston) in the format of the logo of Sprovid općena ${ }^{62}$

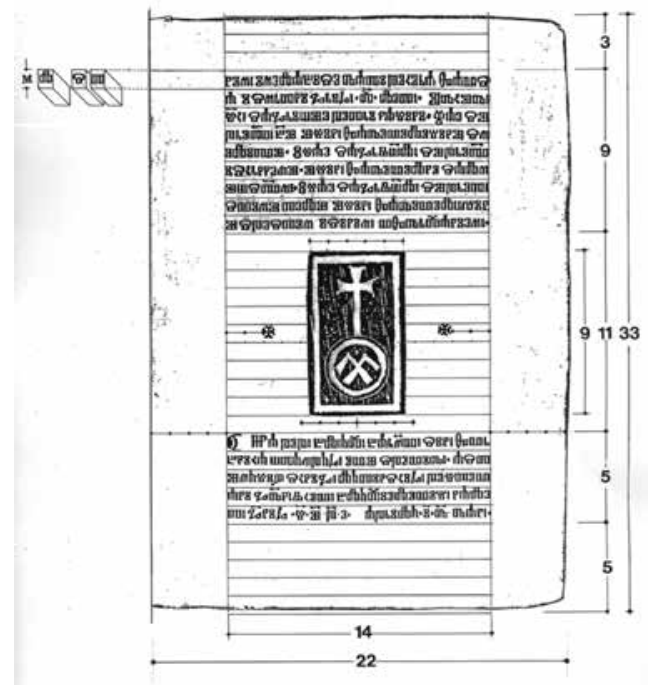

Figure 28. Dimensions on the last page of Sprovid općena (one row $=1$ cic.) ${ }^{62}$

With the knowledge and the gift they had, Blaž Baromić and his team created a book of such a beauty that today's Misal is considered one of the most beautiful incunabula in the world today. Otherwise, the Croatian incunabula can be divided into Glagolitic and Latin.

The Croatian Glagolitic Incunabula are: Misal po zakonu rimskog dvora, Brevijar po zakonu rimskog dvora, Baromićev brevijar, Senjski missal, Spovid općena i Ispovid. Croatian Latin incunabula are: Molitvenik i oficij i Lekcionar Bernadina Spličanina ${ }^{63}$

In addition to the mentioned incunabula there are data that in the 15th century the Zagreb breviary was printed in Venice. In spite of several attempts, Dubrovnik (Ragusa) did not have a print shop of its own until the end of the 18th century. Nevertheless, the lack of print shop at home did not prevent Ragusans from printing many of their works in different European cities.

It is not difficult to conclude from the aforementioned that knowledge about Croatian culture at the turn of the 15th and 16th centuries should be more pronounced in the international community.

"In principio erat verbum - in the beginning there was a word. These words appear to have been written by St. John (Theologies) for the promotion of printing." ${ }^{2}$

In this paper we have tried to argumentatively present the civilization achievements of Croatian regions. We have presented the facts of Croatian graphic print production with its technical and artistic achievements. We hope that this small contribution will help Croatia take the place it belongs to in 
the scientific historical circles. We have chosen the path most beautifully written by Miroslav Krleža: "A small box of metal letters is the utmost that man could do in defense of his dignity."

\section{Reference}

1. Barrett, Timothy, Hugh (2008), The Woman Who Discovered Printing, Great Britain: Yale University Press, ISBN 9780-300-12728-7 (alk paper)

2. Chia Lucille (2011) Knowledge and Text Production ina n Age of Print: China, $900-1409$ Brill

3. Wilkinson, Endymion (2012), Chinese History: A Now Manual, Hardward University Asia Centar for the Hardward Yeuching Institute

4. Ghosh, Pallab „Cave printing ideas abaut the origin of art“. BBC News. „The minimum age for 39,900 years old, which makes it the oldest hand stencil int he world.

5. Pike, A. W. G,Hoffmann, D.L; Garcia - Diaz, M; Pettitt, P. B; Alcolea, J; De Balbin, R; Gonzales - Sainz, C; de las Heras, C; Laskers, J. A; Montes, R.; Zilkaö, J. (15. June 2012) „U -Series Dating of Paleolitic Ar tin 11 Caves in Spain“ Science 336 (6087) $1409-1413$

6. https: // ene Wikipedija. Org/ wiki / History of printing

7. Mary Bellis: The History of Printing and Printing Processes, Early Days of Printing, 29. 7. 2017.

8. The Evolution oft he Book chttps:// sf book. Com / the - evolution - of- the book. htm

9. Fridrick G. Kilgour: The Evolution oft he Book, Oxford University Press $(1998,4)$.

10. Ivan, Cota; Krešimir, Kovačević; Petra, Lauš; Ivan Šimunić; Povijesni razvoj informacijskih znanosti od izuma pisma do 20. stoljeća, Sveučilište u Zagrebu, Filozofski fakultet, Zagreb, 2015.

11. Velimir Salamon, - Ana Herold, - Dubravko Banić, - Zdenka Bolanča; Izrada replike senjske glagoljske preše, Senjski zbornik, godina 35, (2008) 115 - 123

12. Bolanča, Stanislav; Kristijan, Golubović: Tehnologija tiska od Gutenberga do danas, Senjski Zbornik 35 (2008.), Senj, $125-145$.

13. Philipp von Zabern, Das Gutenberg Musseum, Mainz, 1998.

14. Franjo, Mesaroš; Grafička enciklopedija,Tehnička knjiga, Zagreb, 1970.

15. Stanislav, Bolanča; Glavne tehnike tiska, Acta graphica, Zagreb, 1997.

16. $\mathrm{tz}$ - nedeisce. $\mathrm{hr} /$ tiskarka - presa - iz -davnina / 3022

16. B (Rezervna varijanta) History of printing .....(500 x 375 printworks - online. com $)$

17. http://www.ber-ca.com/the -history-of-printing/

18. Early Technnigues for Printing; http://www. Fourgreatinventions, com/ histori of printing (400 x 515 fourgreatinve)

19. www. unicro. hr/print. php? ID $=1983$

20. en. wikipedija. org./ wiki / Gutenberg Bible \# / media / Gutenberg Bible

21. Brophy, P., 2000. The library in the twenty - first century. London: Library Association Publisching.

22. Johanes Gutenberg - From a scan at the Rausom Centar oft he University of Texas at Austin.

23. http://www.hrc.utexas. Edu/exhibitions/permanent/gutenbergbible/rausomcentar/

24. https:// de. Wikipedia. org / wiki / Ausbreitung des Buchdrucks

25. https: // www. museeprotestant. org / de / notice / die - revolution - des -buch drucks - ab - 1445

26. Eisenstein, Elizabeth L. (2005), The Printing Revolution in Early Modern Europe (2nd, rev. ed.), Cambridge University Press, ISBN 0-521-60774-4

27. https: // en. Wikipedia. org / wiki / Global spread of the printing pres

28. Norman F. Blake: Dating the First Books Printed in England. In: Gutenberg - Jahrbuch. Band 1978, 1078,S. 43 - 50 s

29. Gedeon. Borsa: Druckoste in Italien vor 1601

30. Gutenberg - Jahrbuch. Band 1976, 1976, S. 311 - 314

31. Gutenberg - Jahrbuch. Band 1977, 1977, S. 166 - 169

32. hr. wikipedija. org / wiki / Tiskarski strojevi 1450 do 1550.

33. https: // www. Historisches - lexikon -bayerns. De / Leksikon / Buchdruck

34. Ferdinand Gelduer, Die Buchdruckerkunst im alten Bamberg, Bamberg 1964

35. Horst Kunze, Geschichte der Buchillustration in Deutschland, Das 15. Jahrhundert. 2 Teilbände, Frankfurt am Main (u. a.) 1975 .

36. Horst Kunze, Geschichte der Buchillustration in Deutschland. Der 16. Und 17. Jahrhundert, Frankfurt am Main (u. a.) 1993.

37. https://hr.wikipedija.org/wiki/Inkunabula 
38. https://bs.wikipedija.org/wiki/Inkunabula

39. The Invention and History oft he Printing Press htts://www.psprint.com/ resources/printing-press

40. The Printing Press The History Guide www. Historyguide.org/intellect/press.htmi

41. http://apoliti.hr/povijesni-značaj-inkunabula

42. http://shiftbranddesign. com/hr/ identitet/257 - viznalni - identitet - inkunabula

43. Petar Runje: Senjski kulturni krug, Senjski zbornik 35, (2008.) ,Senj, 2008,91-114

44. hattps://hr.wikipedia.org/wiki/ Kosinjska tiskara

45. Glagoljaška štamparija u Kosinju forum.nasa-lika.com/indeks.php? tepic=1906.o

46. Darko Žubrinić, Hrvatski glagoljaški Prvotisak misala iz 1483, 2013.

47. Misal na glagoljici, croatianhistory.net/ef/1483html

48. visitsenj.com/atrakcije/glagoljica-senjska-tiskara

49. Velimir, Salamon; Ana, Herold; Dubravko, Banić; Zdenka, Bolanča: Izrada replike senjske glagoljske preše, Senjski zbornik 35,Senj, (2008), 115 -124

50. https:// hr.wikipedia.org/wiki/Roč

51. https://web.facebook.com/ media/set?

52. https://www.slideshave.net/ivexlibris/latinski-sadržaji-u-ivetu-lokalne-zajednice-kulturom

53. Frane Paro: Grafičkai hrvatski časopis za umjetničku grafiku i nakladništvo. 2 (2004), 3; str. 66 - 67

54. http://www.448x336-najbolje u hrvatskoj.info/ideje/vrbnička-glagoljska-tiskara-vrbnik-4133html

55. https://vrbnik.hr/index.php?option =com

56. fiuminesia.org/rijeka-glagoljska tiskara

57. Stara tiskarska preša - List Međimurja https://međimurje.hr/m-kokice/fotografije/stara-nova-tiskarska -presa-14533/

58. Iz-nedelisce.hr/tiskarska-presa-iz-davnina/

59. Milan, Moguš; Između Mainza i Senja, Senjski zbornik godina 35, (2008) Senj, 5 - 10

60. Juraj, Lokmer: Tiskane glagoljske liturgijske knjige u fondu knjižnice biskupija senjske i modruške u Senju, Senjski zbornik godina 35,(2008) Senj, $161-212$

61. http://www.mainz.de/Gutenberg/erfindu4.htm: Die Erfindung Gutenbergs, Von Mainz in die Welt, Die altesten Druckereien und Verlage

62. Frane, Paro; Tipografsko znanje Blaža Baromića, Senjski zbornik godina 35, (2008) Senj, 147 - 160

63. Anita, Puškarić; Tiskarstvo i ikunabule u Hrvatskoj (Diplomski rad), Sveučilište u Rijeci, Filozofski fakultet, Rijeka, 2014 
